Marketing in Asia Group

\title{
Impact of Music and Colour on Customers' Emotional States: An Experimental Study of Online Store
}

\author{
Aizza Anwar \\ School of Professional Advancement, University of Management and Technology, Pakistan \\ School of Management, Universiti Sains Malaysia, Malaysia \\ Ali Waqas \\ Department of Management Sciences, The Superior University, Pakistan \\ Hafiz Muhammad Zain \\ School of Professional Advancement, University of Management and Technology, Pakistan \\ Daisy Mui Hung Kee \\ School of Management, Universiti Sains Malaysia, Malaysia
}

\begin{abstract}
Retailers try their best to make their online store environment more entertaining and attractive to capture customers' attention. Therefore, it is interesting and beneficial to explore how the store environment impacts the customer emotions in store and how these emotions change customer's buying behaviour. The main focus of this study is to measure the impact of atmosphere cues, such as colour and music on respondent's emotional response and their shopping behaviour in an online store. Respondents were exposed to different combinations of music and colour, and both cues had significant impacts on the respondent's emotional response and behavioural intention. The questionnaire responses of 230 valid respondents from Pakistan revealed that cool colours and fast tempo music showed greater levels of pleasure and arousal as compared to slow tempo music with warm colours. Arousal and pleasure were also found to be significant parameters for predicting behaviour intention. Respondent's in fast tempo music with cool colour environment showed more approach behaviour in comparison to slow tempo music with warm colours. An efficient online store environment is proposed, incorporating suitable music and colour attributes that will result in more time spent in-store, repurchasing, and revisiting. The outcomes of the study assist online retailers in Pakistan to make the shopping environment attractive and enjoyable.
\end{abstract}

Keywords: Atmospheric Cues, Online Store, Online Buying Behaviour, Emotional Response, Behavioural Intention

Publication Details: Received 29 Dec 2019; Revised 26 Mar 2020; Accepted 8 Apr 2020 


\section{Introduction}

There is a popular saying "People will forget what you said, people will forget what you did, but people will never forget how you made them feel,". In the traditional retail context, what customers think of the store environment is based on their feelings and emotions shaped because of aesthetic cues such as store layout music colour pattern etc. while shopping in the store Kotler (1973). Moreover, it was argued that attributes and other qualities like atmosphere gain more attraction of the customer than the product itself. The atmosphere can be defined as the store environment that affects a customer's decisions (Sirgy, Grewal \& Mangleburg, 2000).

The emotional feeling a customer experience upon visiting the store are the store characteristics that attract customers (Berman and Evans, 2013). This holds true even in the case of the online retail industry, website aesthetics provide sensory stimuli that allows visitors to experience impressions (Essawy, 2019). Undoubtedly, due to an increase in the use of the internet online in the retail industry has grown exponentially. However, online retailers still confront many problems. They struggle to develop online shopping experience as exciting and stimulating as the offline shopping experience (Pham \& Ahammad, 2017).

Mehrabian and Russell (1974)'s PAD (Pleasure-Arousal-Dominance) framework, could be used to study store environments. Many researchers have analysed shopping behaviour within the PAD framework and found relationships among emotional states, time spent in store, store experience, shopping behaviours, and tendency to purchase both in traditional store (Dawson, Bloch, \& Ridgway, 1990; Kellaris \& Kent, 1993; Sherman, Mathur \& Smith 1997; Bellizzi, Crowley, \& Hasty, 1983) and web-store ( Abbasi, Goh, \& Ariffin, 2019; Hyllegard, Ogle, Yan \& Kissell, 2016; Lunardo \& Mouangue, 2019; Poncin \& Mimoun, 2014).

The appealing and noteworthy atmospheres of many retail chain outlets create a pleasant experience for the customers, which directly influences a buyer's expectations and decision-making processes (Srinivasan \& Srivastava, 2010). Moreover, improves the shopping experience by providing helpful information about the store (Newman, Dennis \& Zaman, 2006). When a customer feels happy from the store environment, he tends to spend additional time in the store and purchase more, due to the pleasing environmental stimuli (Bohl, 2012). Schmitt (1999) showed that retail environments could provide customers with fascinating experiences that could positively affect their shopping behaviour. The retail store environment is altering due to new technologies that affect shopping experience (Pantano \& Naccarato, 2010). Designers of virtual retail settings use atmospheric cues of physical stores to influence customer's shopping behaviour, which includes music, colour, odour, etc.

Besides the fact that there are few studies (such as Bramley, Dibben \& Rowe 2014; Cheng, Wu \& Yen, 2009) that discussed the importance of music and colour in the online stores, however, there is still lack of research focusing on colour in the online context specially from the perceptive of customer behavioural intention towards the 
products (Putri \& Balqiah, 2017). Additionally, the application of interactive music has not been commonly seen in digital (online) storefronts (Hwang \& Oh, 2020). This study theoretically and practically contributes in the literature by examining the fast vs slow music and understand the consumer behaviour intention. Whereas, the study was conducted in Pakistan retail settings, the studies have not addressed the importance of online retailing in the context of Pakistan's market (Hussain, \& Ali, 2015). Pakistan is one of the developing Asian countries, where people are not inclined towards the online shopping although the internet users have increased recently. Similar trend can be seen in the other Asian countries where the online shopping is not preferred (Putri \& Balqiah, 2017; Hoppe, Lamy \& Cannarsi, 2016) that emphasis on the fact this study would be a good contribution in literature. Therefore, the main goal of the present study is twofold: to measure the effect of two of the most applicable atmospheric cues (music and colour) on customer's emotions for an online store, and to measure the effect on customer's behavioural intentions to buy a product.

\section{Theoretical Background and Research Hypotheses}

\section{Mehrabian-Russell Model}

The framework of this study is established based on Stimulus-Organism-Response (SO-R) Model (Mehrabian \& Russell, 1974). This model comprises three dimensions: stimuli (S), incorporating all environmental cues (such as (ambient, design) that stimulates the emotional response of individual; organism $(\mathrm{O})$, refers to the intervening processes which incorporate the emotions of pleasure, arousal, and dominance; response $(\mathrm{R})$, incorporating human behaviour (approach and avoidance). The model considers a stimulus-organism-response (S-O-R) framework and describes environmental cues, and relevant behaviours in the retail setting and also in virtual reality tourism (Kim, Lee \& Jung, 2019). The S-O-R model focused upon pleasure, arousal, and dominance (PAD) because consumers have three emotional states in response to environmental stimuli. In this study, pleasure and arousal levels measured in the respondent. Previous studies have found that pleasure and arousal elements defined the emotional space induced by the environment well (Russell \& Pratt, 1980), whereas dominance remained of minute significance. Dominance represents cognitive reactions and has been shown to have a non-significant effect on behaviour (Donovan \& Rossiter, 1982, Donovan et al., 1994, Russell \& Pratt, 1980) and failed to demonstrate its effects on approach/avoidance variables (Babin \& Attaway, 2000). Accordingly, in this study authors only selected two emotional states of the respondent: pleasure and arousal. Because they were adequate to signify customer emotional responses in an online store environment. The emotional response results in two different behaviours: either approach or avoidance. Approach refers to the urge to stay and interact with others in the environment (Booms and Bitner, 1980). In contrast, avoidance behaviour includes escaping from the environment (Donovan \& Rossiter, 2002). 


\section{Emotional Responses}

Environmental psychology shows a significant role in studying the interaction between individual and environmental behaviour and supplies a new theoretical perspective for the relationship between the virtual atmosphere and consumers' online buying in the virtual environments. This study used (S-O-R) model focusing on PAD to understand the customer's emotional state (Mehrabian \& Russell, 1974) and study used pleasure and arousal as study variable. Pleasure is the degree to which a person feels happy, joyful, or satisfied with the situation; and arousal is the degree to which a person feels alert, excited, active, or stimulated in the situation (Robert \& John, 1982). Previous researchers (Russell \& Pratt, 1980; Donovan, Rossiter, Marcoolyn \& Nesdale, 1994) used found that pleasure and arousal elements defined the emotional space induced by the environment well. More recent studies used the two dimensions of the model Cheng et al., 2009). Therefore, recent studies have concentrated on pleasure and arousal. Donovan and Rossiter (1982); Eroglu, Machleit, and Davis, (2003); Wu, Cheng, and Yen, (2008) confirmed that the same stimuli impact customer responses in physical as well as in online stores. Similarly, Cheng, Wu \& Leiner (2019) experimental study revealed a significant effect of colour, it has a significant main effect on consumer arousal.

\section{Colour and Emotional Responses}

Colour is an atmospheric variable, which explains the visual appearance of an environment (Bellizzi, Crowley \& Hasty 1983). In a store, colours are used to attract the customer's attention and to change their moods; such as calm, happy, joy and enjoyment (Ou, Luo, Woodcock \&Wright, 2004). Shorter wavelengths are linked with cool colours, e.g. violet and blue, whereas longer wavelengths are linked with warm colours, e.g. red and orange. Generally, white colour is regarded as a neutral colour but is also sometimes categorized as a cool colour (Chebat, Jean Charles \& Morrin, 2007).

Colours influence individuals in diverse ways. Cimbalo, Beck, and Sendziak (1978) examined the relationship among colours and emotions, and classified red, black, and brown as sad colours; and yellow, orange, and blue as happy colours. Kotler (1974) demonstrated that atmospherics, e.g. size, noise, shape, and aroma could help create attention, convey messages, and also create emotions that might boost purchase intentions. Colour is linked with impressions of the retail environment (Bellizzi et al., 1983), anxiety (Jacobs \& Suess, 1975). Colour has a significant impact on consumer behaviour and their buying behaviours, cool colours can stimulate a more positive attitude (Putri \& Balqiah, 2017). Babin, Hardesty, \& Suter (2003) found that shortwavelength hues were favoured and showed a linear relationship between emotional tone and wavelength, with blue environments generally stimulating healthier feelings than orange environments. Jacobs and Hustmyer (1974) argued that red was more stimulating than green, and that blue was more relaxing than red. Psychologically, cool colours (particularly blue) are linked with feelings of pleasantness, calmness, and peacefulness, whereas warm colours (particularly red) are seen as emotionally 
arousing and/or thrilling (Bellizzi et al., 1983; Labrecque, Patrick \& Milne, 2013). Blue (cool colour) is attributed to greater levels of pleasure, while red (warm colour) is linked with greater levels of arousal and assists in product purchase in a shopping environment (Bagchi \& Cheema, 2013). Therefore, we hypothesise:

H1 Subjects exposed to warm background colours in online store will have a greater level of arousal than those exposed to cool colours.

H2 Subjects exposed to cool background colours in online store will have greater pleasure levels than those exposed to warm colours.

\section{Music and Emotional Responses}

Music is normally characterized as organized sound, intended to evoke an aesthetic reaction, and affect physiological feelings (Bitner, 1992) or mood (Shifriss, Bodner \& Palgi, 2019). The type of background music affects the customer's preferences and feelings (Bruner, 1990; Wang, Baker, Wakefield \& Wakefield, 2017). The background music on a website page would increase perceived usefulness and enjoyment among visitors (Wang et al., 2017). Ikeda, (2019) study reported that there is an association between colour and emotion, people comprehend surrounding information and integrate it automatically into the atmosphere.

Positive (cheerful) music should engender positive attitudes, and result in positive ratings and behaviours (Gardner, 1985). Fast music was considered more arousing and more pleasurable than slower tunes (Kellaris \& Kent, 1991, 1993; Bruner, 1990; Sweeney \& Wyber, 2002). Some scholars found that background music could enhance the arousal levels as it affects mood (Ding \& Lin, 2012; Hallam, Price, \& Katsarou, 2002; Wu et al., 2008; Day, Lin, Huang \& Chuang, 2009). Rigg (1964) proposed that music was the most significant feature that defined emotional and psychophysiological responses (Pätynen, \& Lokki, 2016). Fast music is linked with joy, while a slow tempo has always been connected with sadness (Hevner, 1935). A study by Furnham \& Allass (1999) found that fast music-induced better arousal levels than slow music, as the listener had to process more musical information within a given time frame. These studies further strengthen the concept that music can impact customer shopping behaviours. Fast tempo music can enhance the arousal ranks which will, in turn, increase customer physiological arousal. Consequently, it is expected that customers of virtual stores listening to fast tempo music will tend to experience a greater level of arousal as well as pleasure as opposed to slow tempo music. Therefore, we hypothesise:

H3 Subjects exposed to fast tempo music in online store will have greater arousal levels than those exposed to slow tempo music.

H4 Subjects exposed to fast tempo music in online store will have greater pleasure levels than those exposed to slow tempo music. 


\section{Emotional States and Behavioural Intention}

According to emotional states derived from PAD, the consumer's emotional response facilitates the relationship between environmental stimuli and behavioural intention (Jang \& Namkung, 2009). The S-O-R model contends that environmental stimuli affect customer's emotional responses and emotions and induce approach or avoidance behaviours. The approach behaviour contains a customers' positive behavioural response; for example, spending extra time in-store (Donovan \& Rossiter, 1982). In contrast, avoidance evokes a negative behavioural response, spending less money or quitting the store altogether. Since it is difficult to measure the actual behaviour in real-time and place, the concept of approach-avoidance is taken as an attitude towards the act i.e. approach and avoidance intention (Gilboa \& Rafaeli, 2003). Approach intentions are recognized as important antecedents to behaviours and are signs of how eager a customer is to execute the behaviour (Ajzen, 1991).

Earlier research describes the influence of atmospheric factors on customer's purchase intention in conventional (Parsons, 2010; Grewal, Levy, \& Kumar 2009; Mueller \& Mack, 2011) and online (Eroglu et al. 2001, 2003; McKinney, 2004; Manganari, Siomkos \& Vrechopoulos, 2009; Richard, Chebat, Yang \& Putrevu, 2010; Tang \& Zhang, 2018) retail environment. This study is performed to test only the effects of pleasant environments in online store. Therefore, we hypothesise:

H5 Subjects level of pleasure is linked to their behavioural intention in online store.

H6 Subjects level of arousal is linked to their behavioural intention in online store.

\section{Research Methodology}

Eroglu et al. (2003) showed how the environment of an online store could affect customer's emotional and mental states and therefore resolved shopping results. Eroglu et al. (2003); Parsons (2002); and Sautter, Hyman, and Lukosius, (2004) revealed that visual and auditory cues could produce effective reactions in virtual retailing.

Figure. 1: Current Study Research Model

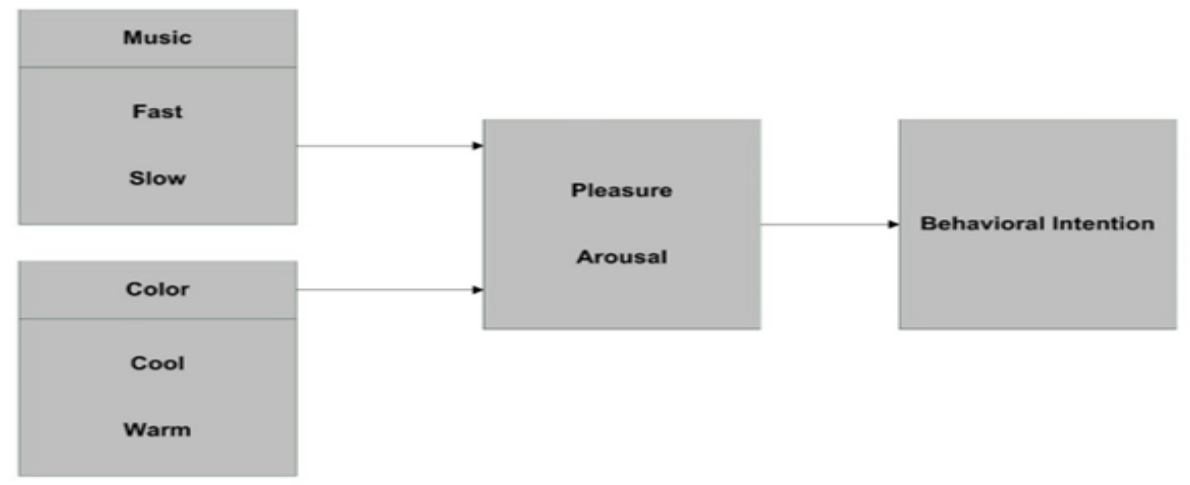


Therefore, visual (background screen colour) and aural (background music) environmental cues were used in the current study. The variables (music and colour) were altered independently, and pleasure and arousal levels measured in the respondents.

\section{Experimental Setup}

This study based on an online store. It was designed with varying types of atmospheric stimuli in accordance with the conditions created for this study. The experiment in our study was a 2 (fast music vs. slow music) x 2 colours (cool colour vs. warm colour) between subjects' factorial design as shown in Table 1, with one control group. According to different music conditions we divided the experiment in three parts. The first one was of fast tempo music in which respondents were assigned to cool and warm colour conditions randomly when they entered in the laboratory. In second part, slow tempo music was played with warm and cool colour conditions.

Figure 2: Cool Background Colour Pages for the Digital Signage Based Online Store

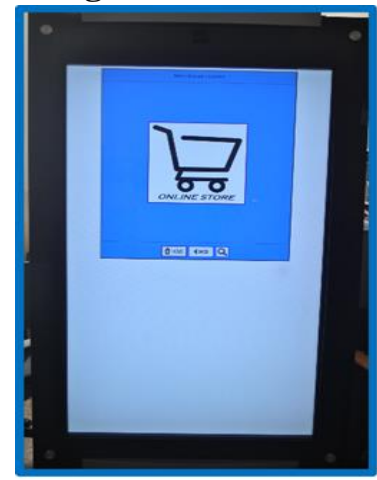

Home Screen

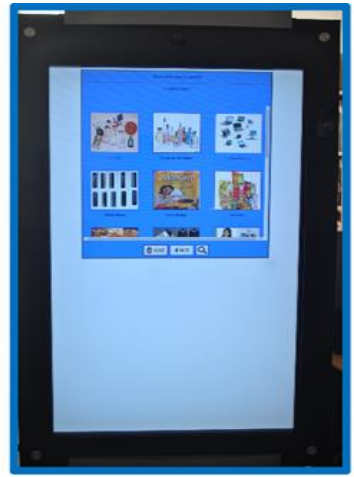

Product Category

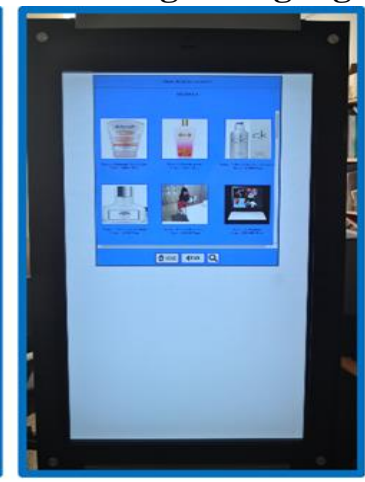

Product List

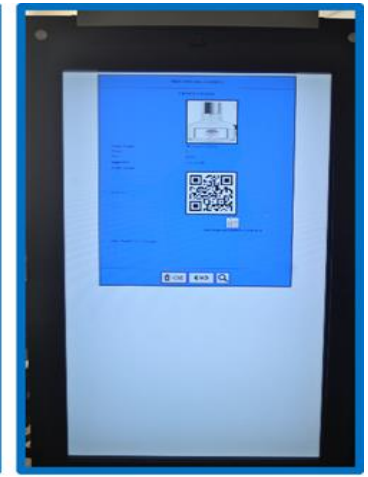

Product Detail

Thirdly, the control group included no music and used white background colour (the white colour is generally perceived as a neutral colour (Chebat et al., 2007). Figures 2 and 3 show the cool and warm background colours, respectively.

Figure 3: Warm Background Colour Pages for the Digital Signage Based Online Store

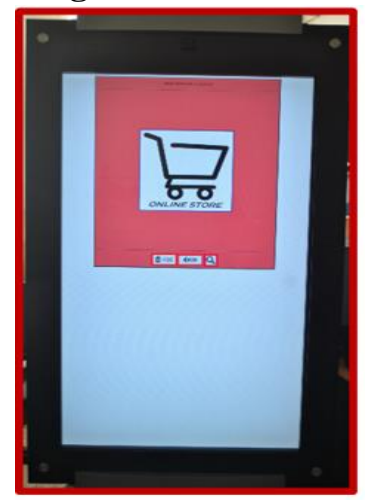

Home Screen

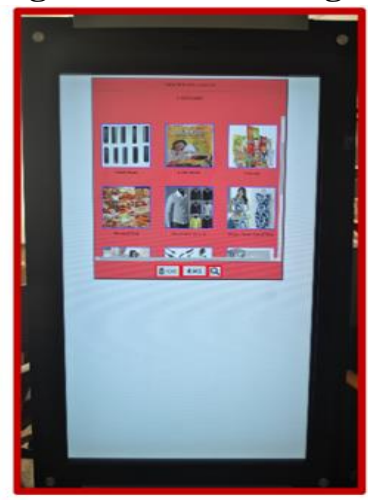

Product Category

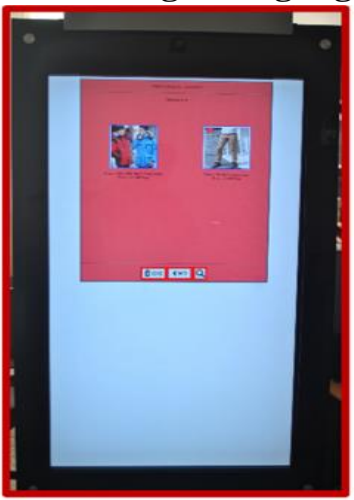

Product List

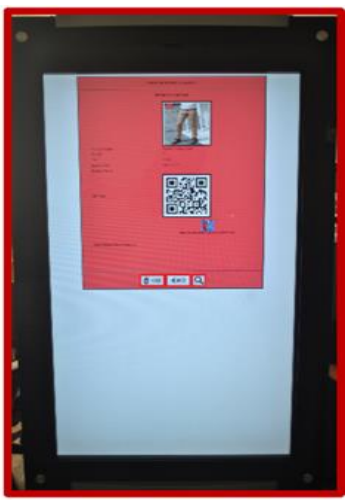

Product Detail 
Prior to actual experiment, a sample of about 20 (15 males and 5 females) respondents pretested the experimental conditions of our study. The results of this preliminary analysis showed that music and colour had a grave impact on emotional states of the customers. The online store had four main pages, consisting of a home screen, product category, product list, and product detail. Product categories included beauty, apparel, electronics, and food. Interface development used the hypertext pre-processor (PHP) language, and the system dataset was stored in MySQL.

Table 1: Factorial Design of the Experiment

\begin{tabular}{ccc}
\hline Group & Color & Music \\
\hline 1 & Cool & Fast \\
\hline 2 & Cool & Slow \\
\hline 3 & Warm & Fast \\
\hline 4 & Warm & Slow \\
\hline 5 - (Control) & White & - \\
\hline
\end{tabular}

Music tempo was measured by beats per minute (BPM). Milliman (1982) classified $120 \mathrm{BPM}$ as fast, and $72 \mathrm{BPM}$ as slow, which has been followed by subsequent researchers Bramley et al. (2014); Caldwell \& Hibbert (1999); Dixon, Trigg, and Griffiths (2007); Spenwyn, Barrett, and Griffiths (2010). Therefore, two songs from similar music collection were used, one slow tempo piece and the other a fast tempo piece.

\section{Measures}

We used Mehrabian and Russell's 12 items semantic differential scale to measure emotional responses to the environment in terms of the 7-points Likert scale (Donovan \& Rossiter, 1982). To measure arousal, six-item pairs were used: relaxbored, happy-unhappy, contented-melancholic, hopeful-despairing, pleased-annoyed, and satisfied-unsatisfied. To measure pleasure, six different item pairs were employed: stimulated-relaxed, aroused-unaroused, wide awake-sleepy, jittery-dull, excited-calm, and frenzied-sluggish. A modified six-item scale (Mehrabian \& Russell, 1974; Donovan \& Rossiter, 1982; Mattila \& Wirtz, 2001) was used to measure behaviour intention with a 7-point Likert scale, authors only focused on positive behaviour intention of respondent:

- I wish to search further about this online store.

- I enjoyed shopping in the online store.

- I liked the online store.

- I am pleased to suggest this online store to friends.

- I will return to this online store in the future.

- I expect to purchase something in this online store. 


\section{Statistical Analyses}

To check the trial design's validity and reliability, factorial analysis using varimax rotation was performed on the questionnaire. A multivariate analysis of variance (MANOVA) was used to measure the effect of environmental stimuli on a respondent's emotional responses, and regression was used to investigate the relationship between behavioural intention and emotional states. All statistical analyses were performed by using the SPSS 23.0 (IBM) for Windows.

\section{Pretest}

Before the study, a pre-test was conducted to assess the psychometric properties of the scale. The 25 respondents ( 15 male and 10 female) who participated in the pre-test had a background of online shopping from both academia and industry. This test helped to determine the limitations and effectiveness of the study. Minor issues were identified in the questionnaire, in which respondents struggled with understanding the phrasing of the questions. As a result, some relatively minor wording improvements were performed to increase participants' understanding. The pre-test also assisted in examining the average time taken by the respondents to finish the survey.

\section{Sample}

To measure the impact of music and colour stimuli on emotional responses, 230 Pakistan students who were not suffering from visual and/or hearing impairments, participated in our study. About fifteen questionnaires were excluded from the study due to unanswered questions. Of the remaining participants, all had an experience of online shopping. The participants were randomly assigned to five groups, each of which had different conditions. Each group in our experiment was composed of 43 participants. Table 2 shows the overall respondent demographics. In particular, $60 \%$ were male, $40 \%$ female; with a decent mixture of undergraduate $(51 \%)$, postgraduate (34\%), and Ph.D. (14\%) students. The majority of respondents (41\%) were 25 years old or younger.

Table 2: Represents the Demographic Characteristics of the Respondents

\begin{tabular}{lllc}
\hline Characteristic & Items & N & Percentage \\
\hline \multirow{4}{*}{ Gender } & Male & 123 & 60.0 \\
& Female & 82 & 40.0 \\
& $0-25$ & 85 & 41.4 \\
\cline { 2 - 4 } Age Range & $26-30$ & 60 & 29.2 \\
& $31-40$ & 45 & 21.9 \\
Education Level & $41-50$ & 15 & 7.5 \\
\cline { 2 - 4 } & Undergraduate & 110 & 51.16 \\
& Postgraduate & 75 & 34.88 \\
Occupation & Ph.D. & 30 & 13.95 \\
\cline { 2 - 4 } & Student & 95 & 46.3 \\
& Professional & 65 & 31.7 \\
& Office worker & 45 & 21.9 \\
\hline
\end{tabular}




\section{Procedure}

After arrival, respondents were randomly placed in groups and informed about the online store. The experiment was carried out in a computer laboratory. Where it was divided into three parts. In the first part, fast tempo music was played, and respondents were randomly assigned to the warm and cool colour conditions after their entry into the laboratory. Everything else in the second one was the same except using a slow tempo music instead of fast music. In the third part (with control group), the control condition was conducted without any music and the colour was erased which resulted into a white background. The authors controlled the effect of performing medium by using only instrumental music performed in Panpipe, while the music was popular broadcast material and by avoiding vocal music, we removed the effect of the song lyrics and controlled for any unintended effect due to a subjects' preference. Two songs from the same music collection (performed by the same singer) were used, one fast and the other slow. Music tempo was manipulated by using a metronome to vary the beats per minute (BPM). Listeners have been found to prefer tempos in a range from 68 to $178 \mathrm{BPM}$. Therefore, we considered a music tempo of 72 BPM or less as slow and 92 or more as fast.

For the current study, approximately 60 products were used in the prototype system and distributed into product and sub-product categories such as in Figure 2 and 3. In the experiment, participants were involved in browsing the different pages of the store, checking the functionalities and reviewing the store environment and the product description offered in store. The whole round of shopping experience was not added, since the ability to physically purchase the product was not granted. The page contents browsed by respondents were identical apart from the difference in background colour and the pace of the music that played on each version of the store. After the simulated shopping experience, respondents were asked to think about feelings, emotions, and moods they experienced while using the online store. Respondents then rated their emotional responses with the aid of the questionnaire. The store environment was planned so that respondents could easily navigate through the store from start to finish.

\section{Empirical Results}

\section{MANOVA Test}

MANOVA is used for comparing multivariate group means and is used when there are two or more dependent variables (Hair, Black, Babin, Anderson \& Tatham, 2006). The main advantage of MANOVA over ANOVA is that multiple ANOVAs increases the likelihood of Type 1 errors, and cannot determine whether or not independent variables are related to combinations of dependent variables. The underlying assumptions for MANOVA include observational independence, multivariate normality, and homogeneity of covariance matrices. Observational independence was assured because respondents were randomly assigned to the different groups, and 
there was no interaction allowed between the respondents. The Shapiro-Wilk test showed the dependent variables were normally distributed. Levene's test showed that the variance homogeneity was met and Box's M test showed univariate homogeneity of the variance.

Table 3: MANOVA Main Effects

\begin{tabular}{llcc}
\hline \multicolumn{2}{c}{ Atmosphere Factor } & \multicolumn{2}{c}{ Emotional States } \\
\cline { 3 - 4 } & & Arousal & Pleasure \\
\hline Colour & & & \\
& F value & $54.80^{* * *}$ & $26.26 * * *$ \\
Music & P value & 0.00 & 0.00 \\
& & & \\
& F value & $50.57 * * *$ & $4.17 * * *$ \\
& P value & 0.00 & 0.00 \\
\hline$* * \mathrm{p}<0.001$ & & &
\end{tabular}

To endorse the likelihood of finding a substantial difference in comparison, we used Tukey's test, sometimes called the honestly significant difference (HSD) test, with significance at $\mathrm{p}<0.05$. Thus, the data meets the underlying assumptions for MANOVA analysis. The main effects of music and colour on respondent emotional stimuli are shown in Table 3 and related descriptive statistics in Table 4.

\section{Colour Effect}

There was a statistically significant difference in emotional responses of respondents based on colour, $\mathrm{F}(3,203)=21.40, \mathrm{p}<0.0005$; Wilk's $\Lambda=0.760$. The post hoc test indicated significant differences between cool, warm, and control colour conditions and no large differences were found between warm and control conditions. Respondents experiencing cool colour felt significantly greater levels of arousal $(\mathrm{p}=$ $0.000)$ and pleasure $(\mathrm{p}=0.000)$ compared to those experiencing warm colour. The mean values $(M)$ for cool colour for arousal and pleasure were $M=4.94$ and $M=$ 4.46, warm $\mathrm{M}=3.84$ and $\mathrm{M}=3.35$, and control $\mathrm{M}=3.57, \mathrm{M}=3.30$, respectively. $\mathrm{A}$ significant difference was found among cool and control colour conditions for pleasure $(\mathrm{p}=0.000)$ and arousal $(\mathrm{p}=0.0015)$, but no significant difference was found among warm and control colour. Thus, Hypothesis 1 was not supported while Hypothesis 2 was supported.

Table 4: Beta Coefficients for the Emotional States

\begin{tabular}{lcccc}
\hline \multicolumn{2}{c}{ Atmosphere Factor } & \multicolumn{2}{c}{ Emotional States } & Behavioural Intention \\
\cline { 3 - 4 } & & Arousal & Pleasure & \\
\hline Colour & Means & Means & Means \\
& Cool & 4.94 & 4.46 & 4.06 \\
Music & Warm & 3.84 & 3.35 & 3.30 \\
& & & & \\
& Fast & 4.61 & 4.44 & 4.58 \\
& Slow & 4.17 & 3.38 & 3.50 \\
Control & & 3.57 & 3.30 & 3.79 \\
\hline
\end{tabular}


The effect of colour on pleasure and arousal showed that respondents perceived cool colour to be more arousing and more pleasurable. Respondents preferred blue (cool) over red (warm) and showed higher levels of arousal (such as excited) and pleasure (such as happy) for blue colour. Previously, the cool colour environment has shown to be perceived as more pleasant and attractive, which enhances the likelihood of purchasing, and produces positive customer attitudes (Bellizzi et al., 1983; Bellizzi, \& Hite, 1992; Middlestadt, 1990). Moreover, Cheng et al., (2019) study also reported similar results that colour have a significant impact on consumer emotional-responses. The current trial confirms these outcomes.

\section{Music Effect}

Statistically significant differences were found between the music tempos, F $(3,203)$ $=25.19, \mathrm{p}<0.0005$; Wilk's $\Lambda=0.729$. Tukey HSD with post hoc comparison was used to investigate where the significance arose. There were significant differences between fast, slow, and control conditions. The mean scores (M) for pleasure and arousal for fast tempo music were $\mathrm{M}=4.61, \mathrm{M}=4.44$, slow $\mathrm{M}=4.17, \mathrm{M}=3.38$, and control $\mathrm{M}=3.57$ and $\mathrm{M}=3.30$, respectively. Respondents experiencing fast tempo music showed considerably greater levels of arousal $(p=0.002)$ and pleasure $(p=$ 0.001) compared to those experiencing slow tempo music. A noteworthy difference was found amongst fast tempo music and control conditions (no music) for respondent arousal $(\mathrm{p}=0.000)$ and pleasure $(\mathrm{p}=0.0012)$. No noteworthy difference was identified between slow tempo music and control conditions for arousal $(\mathrm{p}=$ $1.000)$ or pleasure $(\mathrm{p}=1.000)$. Thus, hypotheses 3 and 4 are both supported. Therefore, fast tempo music is expected to be fruitful in evoking positive emotions among customers in the online store.

\section{Behavioural Intention and Emotional States}

For behavioural intention, we used multiple linear regression for pleasure and arousal as shown in Table 5.

\begin{tabular}{cc}
\begin{tabular}{c} 
Table 5: Beta Coefficients for the Emotional States \\
\hline Emotional
\end{tabular} & Beta Coefficient \\
Response & \\
\hline Pleasure & $0.196 * * *$ \\
Arousal & $0.356^{* * *}$ \\
R2 (adjusted) & 0.403 \\
\hline$* * * p<0.001$ &
\end{tabular}

The regression was significant at $\mathrm{p}<0.001$ for pleasure and arousal and together account for $40.3 \%$ of the variation in approach-avoidance behaviour for the online store. Thus, hypotheses 5 and 6 are both supported. Table 5 shows that cool colour (M $=4.06)$ produced higher approach-avoidance compared to warm colour $(\mathrm{M}=3.30)$, and fast tempo music $(\mathrm{M}=4.58)$ produced higher positive compared to slow tempo music $(\mathrm{M}=3.50)$, both of which further support the relationship between respondent's emotional states and approach-avoidance behaviour. 


\section{Discussion and Implications}

The purpose of the current study is to attain a better understanding of how music and colour impact customers' emotional responses and behaviour intention in an online store. The existing research preliminary starts as an experimental study and assists in improving upon choices in music and colours used in online stores. We wrap up the study by explaining some possible limitations along with directions for future research.

\section{Summary of Results}

The results of MANOVA and regression show that a cool colour store environment with fast tempo music results in greater levels of arousal and pleasure. Moreover, the cool colour store environment and fast tempo music produce greater levels of approach intention. This is aligned with the meta-analysis of 66 studies conducted on atmospheric effects of music and colour on shopping outcome (Roschk, Loureiro \& Breitsohl, 2017).

Colour is distributed into cool and warm colours. As explained in the H1 and H2, warm colours are regarded as more arousing and in contrast, cool colours are considered to be more pleasurable. The results of the MANOVA test shows that respondents felt greater levels of arousal and pleasure in cool colours with lesser levels experienced in warm colour conditions. Moreover, these results are consistent with the studies by Bellizzi et al. (1983); Bellizzi and Hite (1992). This shows that customers liked the blue environment more in comparison to the red one. Interestingly, these results also supported the findings of a previous study by Jacobs, Keown, Worthley, and Ghymn (1991) which suggest that people associate colour with meaning and it influences their behaviour. In accordance, the results of this study reported that cool and warm colours influence customer positive behaviour. While designing the online store environment, cool colours were considered to be more arousing and more pleasurable as compared to warm colours. This does not mean that the designer and retailers should not use warm colours.

The choice of colour is very crucial concerning culture and the country's perspective because each country's culture associates different meaning to the colour and stimulate different approach and avoidance behaviour in the visitor. Our study proposes a greater level of arousal and pleasure by using cool colours rather than warm coolers in Pakistan. In the case of music, we use fast and slow tempo music to measure the impact on emotional responses. As posited in $\mathrm{H} 3$ and $\mathrm{H} 4$, fast music is linked to greater levels of arousal while correspondingly, slow music is linked to higher levels of pleasure. The MANOVA test revealed that fast music is linked with greater levels of arousal and pleasure as compared to slow music. These results align with those of previous studies by Furnham and Allass (1999); Kellaris and Kent (1991); (1993); Bruner (1990); Sweeney and Wyber (2002). The use of fast tempo music in designing the store environment of an online store is considered to be more 
arousing and pleasurable experience that keeps the customer engaged for a longer period of time.

As suggested in H5 and H6, levels of arousal and pleasure of respondents are positively linked with their behavioural intention. Regression analysis shows that music and colour were significant factors that altered customer emotional responses of approach intention in the online retail environment. As it is explained through previous research, behavioural intention is influenced by the emotional state of customers (Donovan \& Rossiter, 1982; Donovan et al., 1994; Machleit \& Eroglu, 2000). Our results show that customers visiting the online store preferred to stay longer, exhibit approach behaviour, when fast tempo music was played in combination with a cool colour. For designing an online store environment, cool colours with fast music are favourable in producing higher levels of pleasure and arousal in customers. These findings in our study offer valued implications for online retailers to enhance the store environment in such a way that customers stay for longer, revisit more and experience more pleasure and arousal.

\section{Theoretical and Managerial Implications}

It is becoming increasingly difficult for retailers to attract customer solely on the basis of product, price, and promotion. The investigation presented in this paper provided fresh insight into the importance of atmospheric cues like music and colour (Roy \& Tai, 2003), that how it generated positive intentions among the customers. The findings of the study theoretically contribute in the literature of music and colour due to experimental settings of the study. It also addressed gap in the literature highlighted by researchers on music (Hwang \& Oh, 2020) and colour (Putri \& Balqiah, 2017). The selection or colour and music on the website stimulates the approach-avoidance behaviour in the customer.

Several managerial implications are highlighted in this study. When designing an online store, managers should try to use all the atmosphere variables to get a better store image. As described by Baker (1986), the visual cues, colour, and layout are considered to be key factors that influence the customer's emotional response and positive behaviour intention towards the store. The choice of music (slow or fast tempo) and colour (cool or warm) is also very critical, and as such, managers should be especially mindful about this aspect. As reported by Milliman (1982), some retailing situations are used to slow down customers' movements so that they will stay longer in-store, leading them to eventually browse more products and buy from the store.

The study highlights the influence of ambient factors on customer emotional responses for online retail environments and provides guidelines for retail managers so that they can modify their store environment accordingly. The success of a retail business lies in providing a better relationship between the customer and the retailer. Retail managers must provide a variety of music and colour options in user-accessible menus to enable customers to enjoy their time in-store. Other important aspects could 
include providing options for customers to select music by singer, song, music type, etc. If the customer likes the colour and music then they will feel happy and stay longer, whereas if they dislike the music and colour feel less satisfied and spend a shorter period in the store. Furthermore, the choice of music should be a key consideration as the wrong choice may lead to noise pollution. Managers should explain to customers how their online store works to benefit their use of an online store. Better results are possible when there is a partnership between environmental psychology, retailing, and marketing. We assumed that every respondent could see colours and hear the music in our study.

\section{Implications for Business Marketing Practice}

The influence of the internet has grown stronger every day. The businesses have understood that and strategized their marketing practices accordingly. Every CEO understands the importance of virtual presence, it can make or break a business. It could be in the form of a website, an e-commerce platform, a social media page or a blog. If customers would not see the business online, the opportunity to increase your customer and get the word out about your business would be lost.

Online shopping is getting popular among every generation as they feel it more comfortable, time-saving and convenient. These days if someone wants to learn more about a company, they would search online. Similarly, if someone wants to find out about particular products or services that a company is offering, they would go online. Therefore, this study focuses on atmospheres creating a pleasant experience for the customers has very significant implication for businesses. The study highlights the influence of ambient factors on customer emotional responses for online retail environments and provides guidelines for retail managers so that they can modify their store environment accordingly. The retail managers must provide a variety of music and colour options in user-accessible menus to enable customers to enjoy their time in-store (virtual). Other important aspects could include providing options for customers to select music by singer, song, music type, etc. If the customer likes the colour and music then they will feel happy and stay longer on website. It leading them to eventually browse more products and buy from the store.

Moreover, through e-business different type businesses has gained an opportunity to increase their sale and can maintain a direct relationship with its customers without any other person or entity. when a consumer makes a mind to purchase online electronic goods he or she is affected by multiple factors. The flexibility and freedom to compare prices in online stores and then review all feedbacks and rating about product and allow the customers to make a better decision. E-commerce has made life simple and innovative for individuals and groups; consumer behaviour in online shopping is different from the physical market where he has access to see the product. The main crucial factors are time saving, at the best price and convenience. The best price factor is one of major reason of e-businesses. The online products prices are lower as against the physical markets. It is not only to facilitate the e-business but also it allows business to compete on cost because they need less physical presence. The 
literature also argues that cost and competitive prices, makes Internet shopping popular among consumers. However, what makes one e-business virtual presence better from the other is how managers try to use all the atmosphere variables in order to get a better store image. The visual cues, colour, and layout are considered to be key factors that influence the customer's emotional response and approach or avoidance intention to the store. The choice of music (slow or fast tempo) and colour (cool or warm) is also very critical, Thus, this study has strong business implication for virtual businesses that website atmosphere is used to slow down customers' movements so that they will stay longer in- in-store, leading them to eventually browse more products and buy from the store.

\section{Limitations and Directions for Future Research}

The present study has some limitations that should be kept in mind while interpreting results. Firstly, the use of a student sample shows a potential limitation that may shorten the generalization of results to other settings. The studies by Gao and $\mathrm{Wu}$ (2010); Huang (2008); Rosen and Purinton (2004); Wells, Valacich, and Hess (2011) use student samples; students provide an adequate sample to study online shopping behaviour (Gao \& Koufaris,2006; Ha \& Stoel, 2008). The research hypothesis should be examined with more extensive and varied sections of online consumer studies. Second, only two colours and music types were investigated. With a wider variety of colours and music, better results could be achieved in online consumer studies. Lastly, a whole shopping environment involves searching, evaluating, selecting, ordering and the final payment for the products (Shih, 2004). In our study, we used a sample online store that did not allow access to some features, such as ordering, payment, postpayment checking, shipping options, etc.

Therefore, future research should mimic the current study but in a field study with an actual online store equipped for the aforementioned purposes, from searching to ordering and payment to shipment. The existing study explores valuable areas of research. Continuing in future studies, the use of facial expression analysis to detect and comprehend customers' facial expressions could be greatly beneficial. The customers' facial expressions will be measured in real-time using the webcam, and directly assess the impact of the music, colour on the store environment. Future work may also focus on examining facial expressions in combination with their emotional states in real-time, with consideration of diverse environmental cues.

\section{Conclusions}

To conclude, the present study demonstrates the impact of different music and colour schemes on users. Its findings complement previous research on websites. An online store is a novel way of shopping in the online retail market. Based on the Mehrabian and Russell model (S-O-R), the findings of the study provide both theoretical and practical contributions and help to simplify the impact of music and colour on 
customer's emotional states. Future research using other theories related to customer's behaviour will help to improve the shopping and store environment.

\section{Implications for Asian Business Context}

The purpose of the current study is to attain a better understanding of how music and colour impact customers' emotional responses and approach towards the online store. It has been discussed in the literature that the online purchase behaviour of consumers is almost similar around the globe. world. The access of the internet has turned the world into a global village. The technological advancements have changed the way people live their life. Now, we have friends online with whom we share our lives and interests. The number of internet users has been increasing over the year and it is also true in the Asian context. The internet is also popular among the young generation. They spend most of their time on the internet in the form of social networking sites or shopping websites. Therefore, the implications of this study are stronger for the Asian business context. Today every business has a virtual presence either in the form of a website or blog. E-business has emerged to be one of the most important marketing and sales tool. The appealing and noteworthy atmospheres of many retail chain outlets create a pleasant experience for the customers, which directly influences a buyer's expectations and decision-making processes. It provides customers with fascinating experiences that positively affect their shopping behaviour. When a customer feels happy from the store environment, he/she tends to spend additional time in the store and purchase more, due to the pleasing environment. Moreover, it helps the seller to reach the customer who lives in the areas where they cannot have a physical presence. Consequently, it also allows the business to offer the lowest price possible as against the physical markets. This also gives rise to the idea of boundaryless businesses like Alibaba. Because businesses can avoid rental costs and employee costs. This, in turn, encourages the consumer to purchase anything that is available on the internet.

\section{References}

Abbasi, G. A., Goh, Y. N., \& Ariffin, S. K., (2019), "Stimulating online buying behaviour among millennials in Pakistan: A conceptual model and research propositions", Journal of Entrepreneurship, Business and Economics, vol. 7, no. 2, pp. 189-219.

Ajzen, I., (1991), "The theory of planned behaviour", Organizational Behaviour and Human Decision Processes, vol. 50, no. 2, pp. 179-211.

Babin, B. J., \& Attaway, J. S., (2000), "Atmospheric affect as a tool for creating value and gaining share of customer", Journal of Business Research, vol. 49, no. 2, pp. 91-99.

Babin, B. J., Hardesty, D. M., \& Suter, T. A., (2003), "Colour and shopping intentions: The intervening effect of price fairness and perceived affect", Journal of Business Research, vol. 56, no. 7, pp. 541-551.

Bagchi, R., \& Cheema, A., (2013), "The effect of red background colour on willingness-topay: The moderating role of selling mechanism", Journal of Consumer Research, vol. 39, no. 5, pp. 947-960.

Baker, J., (1986), "The role of the environment in marketing services: The consumer perspective", American Marketing Association, vol. 1, no. 1, pp. 79-84. 
Bellizzi, J. A., Ayn, E. C., \& Ronald, W. H., (1983), "The effects of colour in store design", Journal of Retailing, vol. 59, no. 1, pp. 21-45.

Berman, B. R., \& Evans, J. R., (2013), Retail management: A strategic approach, Pearson Education, London.

Bitner, M. J., (1992), "Servicescapes: The impact of physical surroundings on customers and employees", Journal of Marketing, vol. 56, no. 2, pp. 57-71.

Bohl, P., (2012), "The effects of store atmosphere on shopping behaviour: A literature review", Corvinus Marketing Studies, vol. 2012, no. 1, pp. 1-23.

Booms, B. H., \& Bitner, M. J., (1982), "Marketing services by managing the environment", Cornell Hotel and Restaurant Administration Quarterly, vol. 23, no. 1, pp. 35-40.

Bramley, S., Dibben, N., \& Rowe, R., (2014), "The influence of background music tempo and genre on virtual roulette", Journal of Gambling Issues, vol. 29, pp. 1-12.

Bruner, G. C., (1990), "Music, mood, and marketing", Journal of Marketing, vol. 54, no. 4, pp. 94-104.

Caldwell, C., \& Hibbert, S. A., (1999), "Play that one again: The effect of music tempo on consumer behaviour in a restaurant", E-European Advances in Consumer Research, vol. 4, pp. 58-62.

Chebat, J-C., \& Maureen, M., (2007), "Colours and cultures: Exploring the effects of mall décor on consumer perceptions", Journal of Business Research, vol. 60, no. 3, pp. 189196.

Chen, Q., Malric, F., Zhang, Y., Abid, M., Cordeiro, A., Petriu, E. M., \& Georganas, N. D., (2009), Interacting with digital signage using hand gestures, In International Conference Image Analysis and Recognition, Springer Berlin Heidelberg.

Cheng, F. F., Wu, C. S., \& Leiner, B., (2019), "The influence of user interface design on consumer perceptions: A cross-cultural comparison", Computers in Human Behaviour, vol. 101, pp. 394-401.

Cheng, F. F., Wu, C. S., \& Yen, D. C., (2009), "The effect of online store atmosphere on consumer's emotional responses-An experimental study of music and colour", Behaviour \& Information Technology, vol. 28, no. 4, pp. 323-334.

Cimbalo, R. S., Beck, K. L., \& Sendziak, D. S., (1978), "Emotionally toned pictures and colour selection for children and college students", Journal of Genetic Psychology, vol. 133, no. 2, pp. 303-304.

Cleland, T. M., (1969), A grammar of colour: A basic treatise on the colour system of Albert H. Munsell, Van Nostrand Reinhold Co, New York.

Dawson, S., Bloch, P. H., \& Ridgway, N., (1990), "Shopping motives and emotional states", Journal of Retailing, vol. 66, no. 4, pp. 408-427.

Day, R. F., Lin, C. H., Huang, W. H., \& Chuang, S. H., (2009), "Effects of music tempo and task difficulty on multi-attribute decision-making: An eye-tracking approach", Computers in Human Behaviour, vol. 25, no. 1, pp. 130-143.

Ding, C. G., \& Lin, C. H., (2012), "How does background music tempo work for online shopping?", Electronic Commerce Research and Applications, vol. 11, no. 3, pp. 299307.

Dixon, L., Trigg, R., \& Griffiths, M., (2007), "An empirical investigation of music and gambling behaviour", International Gambling Studies, vol. 7, no. 3, pp. 315-326.

Donovan, R. J., \& Rossiter, J. R., (2002), "Store atmosphere: An environmental psychology approach. Retailing: Critical concepts", Retail Practices and Operations, vol. 2, no. 1, pp. 77.

Donovan, R. J., Rossiter, J. R., Marcoolyn, G., \& Nesdale, A., (1994), "Store atmosphere and purchasing behaviour", Journal of Retailing, vol. 70, no. 3, pp. 283-294.

Eroglu, S. A., Machleit, K. A., \& Davis, L. M., (2003), "Empirical testing of a model of online store atmospherics and shopper responses", Psychology \& Marketing, vol. 20, no. 2, pp. 139-150.

Essawy, M., (2019), "The impacts of e-atmospherics on emotions and on the booking intentions of hotel rooms", Tourism and Hospitality Research, vol. 19, no. 1, pp. 65-73. 
Furnham, A., \& Allass, K., (1999), "The influence of musical distraction of varying complexity on the cognitive performance of extroverts and introverts", European Journal of Personality, vol. 13, no. 1, pp. 27-38.

Gao, Y., \& Koufaris, M., (2006), "Perceptual antecedents of user attitude in electronic commerce", ACM SIGMIS Database, vol. 37, no. 2-3, pp. 42-50.

Gao, Y., \& Wu, X., (2010), "A cognitive model of trust in e-commerce: Evidence from a field study in China", Journal of Applied Business Research, vol. 26, no. 1, pp. 37-44.

Gardner, M. P., (1985), "Mood states and consumer behaviour: A critical review", Journal of Consumer Research, vol. 12, pp. 281-300.

Gilboa, S., \& Rafaeli, A., (2003), "Store environment, emotions and approach behaviour: Applying environmental aesthetics to retailing", The International Review of Retail, Distribution and Consumer Research, vol. 13, no. 2, pp. 195-211.

Grewal, D., Levy, M., \& Kumar, V., (2009), "Customer experience management in retailing: An organizing framework", Journal of Retailing, vol. 85, no. 1, pp. 1-14.

Guilford, J. P. \& Smith, P. C., (1959), "A system of colour preferences", American Journal of Psychology, vol. 72, no. 4, pp. 487-502.

Ha, S., \& Stoel, L., (2009), "Consumer e-shopping acceptance: Antecedents in a technology acceptance model”, Journal of Business Research, vol. 62, no. 5, pp. 565-571.

Hair, J. F., Black, W. C., Babin, B. J., Anderson, R. E., \& Tatham, R. L., (2006), Multivariate data analysis, Pearson Education, London.

Hallam, S., Price, J., \& Katsarou, G., (2002), "The effects of background music on primary school pupils' task performance", Educational Studies, vol. 28, no. 2, pp. 111-122.

Hevner, K., (1935), "The affective character of the major and minor modes in music", The American Journal of Psychology, vol. 47, no. 1, pp. 103-118.

Hoppe, F., Lamy, S., \& Cannarsi, A., (2016), "Can Southeast Asia live up to its e-commerce potential", Retrieved from https://www.bain.com/insights/can-se-asia-live-up-to-itsecommerce-potential/

Huang, E., (2008), "Use and gratification in e-consumers", Internet Research, vol. 18, no. 4, pp. 405-426.

Hussain, R., \& Ali, M., (2015), "Effect of store atmosphere on consumer purchase intention", International Journal of Marketing Studies, vol. 7, no. 2, pp. 35-43.

Hwang, A. H. C., \& Oh, J., (2020), "Interacting with background music engages e-customers more: The impact of interactive music on consumer perception and behavioural intention", Journal of Retailing and Consumer Services, vol. 54, pp. 1-15.

Hyllegard, K. H., Ogle, J. P., Yan, R. N., \& Kissell, K., (2016), "Consumer response to exterior atmospherics at a university-branded merchandise store", Fashion and Textiles, vol. 3 , no. 1, pp. 1-17.

Ikeda, S., (2019), "Influence of colour on emotion recognition is not bidirectional: An investigation of the association between colour and emotion using a stroop-like task", Psychological Reports, pp. 1-14.

Jacobs, K. W., \& Hustmyer, F. E., (1974), "Effects of four psychological primary colours on GSR, heart rate and respiration rate", Perceptual and Motor Skills, vol. 38, no. 3, pp. 763-766.

Jacobs, K. W., \& Suess, J. F., (1975), "Effects of four psychological primary colours on anxiety state", Perceptual and Motor Skills, vol. 41, no. 1, pp. 207-210.

Jacobs, L., Keown, C., Worthley, R., \& Ghymn, K. I., (1991), "Cross-cultural colour comparisons: global marketers beware!”, International Marketing Review, vol. 8, no. 3, pp. 21-30.

Jang, S. S., \& Namkung, Y., (2009), "Perceived quality, emotions, and behavioural intentions: Application of an extended Mehrabian-Russell model to restaurants", Journal of Business Research, vol. 62, no. 4, pp. 451-460.

Kellaris, J. J., \& Kent, R. J., (1991), "Exploring tempo and modality effects, on consumer responses to music", NA-Advances in Consumer Research, vol. 18, pp. 243-248. 
Kellaris, J. J., \& Kent, R. J., (1993), "An exploratory investigation of responses elicited by music varying in tempo, tonality, and texture", Journal of Consumer Psychology, vol. 2, no. 4, pp. 381-401.

Kim, M. J., Lee, C. K., \& Jung, T., (2019), "Exploring consumer behaviour in virtual reality tourism using an extended stimulus-organism-response model, Journal of Travel Research, pp. 1-21.

Kotler, P., (1973), Atmospherics as a marketing tool, Journal of Retailing, vol. 49, no. 4, pp. 48-64.

Labrecque, L. I., Patrick, V. M., \& Milne, G. R., (2013), “The marketers' prismatic palette: A review of colour research and future directions", Psychology \& Marketing, vol. 30, no. 2, pp. 187-202.

Lee, S., \& Koubek, R. J., (2010), "The effects of usability and web design attributes on user preference for e-commerce web sites", Computers in Industry, vol. 61, no. 4, pp. 329341.

Lunardo, R., \& Mouangue, E., (2019), "Getting over discomfort in luxury brand stores: How pop-up stores affect perceptions of luxury, embarrassment, and store evaluations", Journal of Retailing and Consumer Services, vol. 49, pp. 77-85.

Machleit, K. A., \& Eroglu, S. A., (2000), "Describing and measuring emotional response to shopping experience", Journal of Business Research, vol. 49, no. 2, pp. 101-111.

Manganari, E. E., Siomkos, G. J., \& Vrechopoulos, A. P., (2009), "Store atmosphere in web retailing", European Journal of Marketing, vol. 43, no. 9/10, pp. 1140-1153.

Mattila, A. S., \& Wirtz, J., (2001), "Congruency of scent and music as a driver of in-store evaluations and behaviour", Journal of Retailing, vol. 77, no. 2, pp. 273-289.

McKinney, L. N., (2004), "Creating a satisfying internet shopping experience via atmospheric variables", International Journal of Consumer Studies, vol. 28, no. 3, pp. 268-283.

Mehrabian, A., \& Russell, J. A., (1974), An approach to environmental psychology, The MIT Press, Cambridge.

Middlestadt, S. E., (1990), "The effect of background and ambient colour on product attitudes and beliefs", NA-Advances in Consumer Research Volume, vol. 17, pp. 244-249.

Milliman, R. E., (1982), "Using background music to affect the behaviour of supermarket shoppers", Journal of Marketing, vol. 46, no. 3, pp. 86-91.

Mueller, J. D., \& Mack, R., (2011), "Website atmospherics: Motivators or hygiene factors?", Journal of Business \& Economics Research, vol. 1, no. 6, pp. 73-82.

Newman A., Dennis C. E., \& Zaman, S., (2006), "Marketing images and consumers' experiences in selling environments", Marketing Management Journal, vol. 17, no. 1, pp. 515-519.

Ong, T., (2017), "Samsung's new app helps people who are colour blind recalibrate colours on their TVs", Retrieved from https://www.theverge.com/circuitbreaker/2017/11/28/ 16709600/samsung-seecolors-app-color-blind

Ou, L. C., Luo, M. R., Woodcock, A., \& Wright, A., (2004), "A study of colour emotion and colour preference. Part I: Colour emotions for single colours", Colour Research \& Application, vol. 29, no. 3, pp. 232-240.

Pantano, E., \& Naccarato, G., (2010), "Entertainment in retailing: The influences of advanced technologies", Journal of Retailing and Consumer Services, vol. 17, no. 3, pp. 200-204.

Parsons, A. G., (2002), "Non-functional motives for online shoppers: Why we click", Journal of Consumer Marketing, vol. 19, no. 5, pp. 380-392.

Parsons, A. G., (2011), “Atmosphere in fashion stores: do you need to change?", Journal of Fashion Marketing and Management: An International Journal, vol. 15, no. 4, pp. 428445.

Pätynen, J., \& Lokki, T., (2016), "Concert halls with strong and lateral sound increase the emotional impact of orchestra music", The Journal of the Acoustical Society of America, vol. 139, no. 3, pp. 1214-1224.

Pham, T. S. H., \& Ahammad, M. F., (2017), "Antecedents and consequences of online customer satisfaction: A holistic process perspective", Technological Forecasting and Social Change, vol. 124, pp. 332-342. 
Poncin, I., \& Mimoun, M. S. B., (2014), "The impact of "e-atmospherics" on physical stores", Journal of Retailing and Consumer Services, vol. 21, no. 5, pp. 851-859.

Putri, K. D., \& Balqiah, T. E., (2017), "Do Web atmospherics affect purchase intention? The role of colour and product display", Journal of Management and Marketing Review, vol. 2, no. 2, pp. 79-86.

Richard, M. O., Chebat, J. C., Yang, Z., \& Putrevu, S., (2010), “A proposed model of online consumer behaviour: Assessing the role of gender", Journal of Business Research, vol. 63, no. 9, pp. 926-934.

Rigg, M. G., (1964), "The mood effects of music: A comparison of data from four investigators", Journal of Psychology, vol. 58, no. 2, pp. 427-438.

Robert, D., \& John, R., (1982), "Store atmosphere: An environmental psychology approach", Journal of Retailing, vol. 58, no. 1, pp. 34-57.

Roschk, H., Loureiro, S. M. C., \& Breitsohl, J., (2017), "Calibrating 30 years of experimental research: A meta-analysis of the atmospheric effects of music, scent, and colour, Journal of Retailing, vol. 93, no. 2, pp. 228-240.

Rosen, D. E., \& Purinton, E., (2004), "Website design: Viewing the web as a cognitive landscape", Journal of Business Research, vol. 57, no. 7, pp. 787-794.

Roy, A., \& Tai, S. T., (2003), "Store environment and shopping behaviour: The role of imagery elaboration and shopping orientation", Journal of International Consumer Marketing, vol. 15, no. 3, pp. 71-99.

Russell, J. A., \& Pratt, G., (1980), "A description of the affective quality attributed to environments", Journal of Personality and Social Psychology, vol. 38, no. 2, pp. 311322.

Sautter, P., Hyman, M. R., \& Lukosius, V., (2004), "E-tail atmospherics: A critique of the literature and model extension", Journal of Electronic Commerce Research, vol. 5, no. 1 , pp. 14-24.

Schmitt, B., (1999), "Experiential marketing", Journal of Marketing Management, vol. 15, no. 1-3, pp. 53-67.

Sherman, E., Mathur, A., \& Smith, R. B., (1997), "Store environment and consumer purchase behaviour: Mediating role of consumer emotions", Psychology and Marketing, vol. 14, no. 4, pp. 361-378.

Shifriss, R., Bodner, E., \& Palgi, Y., (2019), "Don't let me down: The effect of age and chosen music on mood is moderated by focus on emotions", Journal of Positive Psychology, 1-13.

Shih, H. P., (2004), "An empirical study on predicting user acceptance of e-shopping on the web", Information \& Management, vol. 41, no. 3, pp. 351-368.

Sirgy, M. J., Grewal, D., \& Mangleburg, T., (2000), "Retail environment, self-congruity, and retail patronage: An integrative model and a research agenda", Journal of Business Research, vol. 49, no. 2, pp. 127-138.

Spenwyn, J., Barrett, D. J., \& Griffiths, M. D., (2010), "The role of light and music in gambling behaviour: An empirical pilot study", International Journal of Mental Health and Addiction, vol. 8, no. 1, pp. 107-118.

Srinivasan, S. R., \& Srivastava, R. K., (2010), "Creating the futuristic retail experience through experiential marketing: Is it possible? An exploratory study", Journal of Retail \& Leisure Property, vol. 9, no. 3, pp. 193-199.

Sweeney, J. C., \& Wyber, F., (2002), "The role of cognitions and emotions in the musicapproach-avoidance behaviour relationship", Journal of Services Marketing, vol. 16, no. 1, pp. 51-69.

Tang, J., \& Zhang, P., (2018), “The impact of atmospheric cues on consumers' approach and avoidance behavioural intentions in social commerce websites", Computers in Human Behaviour, pp. 1-35.

Wang, L., Baker, J., Wakefield, K., \& Wakefield, R., (2017), "Is background music effective on retail websites?", Journal of Promotion Management, vol. 23, no. 1, pp. 1-23. 
Wells, J. D., Valacich, J. S., \& Hess, T. J., (2011), "What signals are you sending? How website quality influences perceptions of product quality and purchase intentions", MIS Quarterly, vol. 35, no. 2, pp. 373-396.

Wu, C. S., Cheng, F. F., \& Yen, D. C., (2008), "The atmospheric factors of online storefront environment design: An empirical experiment in Taiwan", Information \& Management, vol. 45, no. 7 , pp. 493-498. 